\title{
Sunflower Seed Protein Content in Relation to Desiccation Date and Seed Moisture
}

\author{
Petar Čanak • Velimir Radić • Milan Jocković • Radovan Marinković • \\ Mihajlo Ćirić • Jelena Mrđa • Vladimir Miklič
}

\author{
received: 11 November 2011, accepted: 12 December 2011 . \\ (C) 2012 IFVC \\ doi: $10.5937 /$ ratpov $49-1180$
}

\begin{abstract}
Summary: The objective of this study was to investigate the effect of desiccation date and seed moisture content on sunflower seed protein content. The experimental materials were three new parental sunflower lines of the Institute of Field and Vegetable Crops from Novi Sad, Serbia (L1, L2 and L3). Reglone forte $\left(21 \mathrm{ha}^{-1}\right)$ was used for desiccation and it was applied at 7-day intervals from the end of flowering to harvest maturity. The protein content was determined by the classical method of Kjeldabl. The stabilization of the protein content was determined in treatment that was performed 21 days after flowering (DAF) at seed moisture of about $45 \%$. Regression analysis determined the highest and statistically significant effect of seed moisture at the moment of desiccation on seed protein content in the line L1, while the effects in lines L2 and L3 were not significant.
\end{abstract}

Key words: desiccants, moisture, protein contents, seed protein, sunflower seed

\section{Introduction}

Sunflower (Helianthus annuus) is the most important oil crop in Serbia (Miklič et al. 2010). It is also an important source of protein (Stanković et al. 2003). Sunflower meal as a byproduct of oil extraction is used as an excellent livestock feed. It is a source of biologically valuable proteins and if properly processed, it has a usable value of protein and amino acid composition similar to soybean meal (Lević et al. 2005). The increasing use of biodiesel will result in increased area under oil crops and increased amount of sunflower meal as a by-product (Kovčin \& Stanaćev 2006). The protein content ranges from $32-38 \%$ in sunflower meal, and $13-20 \%$ in sunflower seed (Jevtic et al. 1986). Majority of proteins present in fully developed seeds have structural or metabolic roles. Besides these roles, proteins in seeds also serve to provide a store of amino acids needed for germination and early seedling growth (Shewry et al. 1995).

Desiccation was introduced in agricultural practice as an agrotechnical measure several decades ago. The basic idea is to accelerate plant

P. Čanak* • V. Radić • M. Jocković • R. Marinković • M. Ćirić • J. Mrđa • V. Miklič

Institute of Field and Vegetable Crops, Maksima Gorkog 30, 21000 Novi Sad, Serbia

e-mail:petar.canak@ifvcns.ns.ac.rs drying in order to make the crop ready for early harvest. The measure is advantageous in cool climates, where spring crops often mature in late fall, when weather conditions make harvest difficult. Chemical desiccation largely solves the problems occurring in mechanical sunflower harvest (Miklič et al. 2001).

Desiccation can be performed with chemicals such as diquat, glufosinate-ammonium, dimetipin, etc. (Đukić et al. 2007). Miklič et al. (2006) have obtained the best results with Reglone forte application (2 $1 \mathrm{ha}^{-1}$ with 300-400 1 of water). Diquat, which is the active substance of herbicide Reglone forte, is not soluble in oil and it is not found in sunflower meal (Hill et al. 1974).

The objective of the study was to investigate the effect of desiccation date and seed moisture content on sunflower seed protein content, i.e. to determine ending of protein accumulation in seed.

\section{Materials and Methods}

The trial was conducted at Rimski Šančevi during 2009 and included three new cytoplasmic male sterile lines of sunflower developed at

Acknowledgement: This study is a part of research on the project TR31025 "Development of new varieties and production technology improvement of oil crops for different purposes" funded by the Ministry of Science and Education of the Republic of Serbia 
Institute of Field and Vegetable Crops, Novi Sad, Serbia (L1, L2 and L3). Desiccation was performed with Reglone forte (2 $\left.1 \mathrm{ha}^{-1}\right)$ applied at 7-day intervals from the end of flowering (DAF-days after flowering) to harvest maturity (control). There were 6 desiccation treatments (in the period 3 August 2009-7 September 2009) and the control (14 September 2009). Treatments were performed with a knapsack sprayer. Seed samples from several sunflower heads were collected directly before each treatment in order to test the moisture content in seed at the time of treatment. Seed moisture was determined in the laboratory by the conventional gravimetric method. When harvest maturity was reached, 12 heads were taken from each treatment to make average samples for protein content analysis. The analysis was performed by the Kjeldahl method in three replications.

The results were statistically processed. The analysis of variance of two-factorial experiment (split-plot design) and the regression analysis (quadric) were used. Significance of regression was tested with the F-test.

\section{Results and Discussion}

In all three lines there was a reduction of seed moisture content from the treatment 7 DAF to the control. Average seed moisture content decreased from $73.07 \%$ to $8.98 \%$ (Tab. 1).

The highest average protein content was found in the line L1 (21.52\%), the lowest in the line L3 (16.75\%). The average protein content in the line L1 was highly significant in relation to the line L3. Between lines L1 and L2 there was no significant difference in the average protein content (Tab. 2). The control had the highest average protein content (20.39\%), while the lowest protein content was found in treatment 7 DAF (18.78\%). The protein content in the control was highly significant in relation to the treatments $7 \mathrm{DAF}$ and 14 DAF. Other treatments showed no significant difference in protein content in relation to the control. This result could indicate that protein accumulation in sunflower seed ends at $21 \mathrm{DAF}$ (at seed moisture of $45.6 \%$ ), because there was no subsequent increase in protein content.

Table 1. Seed moisture content at the time of desiccation (\%)

Tabela 1. Sadržaj vlage u semenu u momentu desikacije (\%)

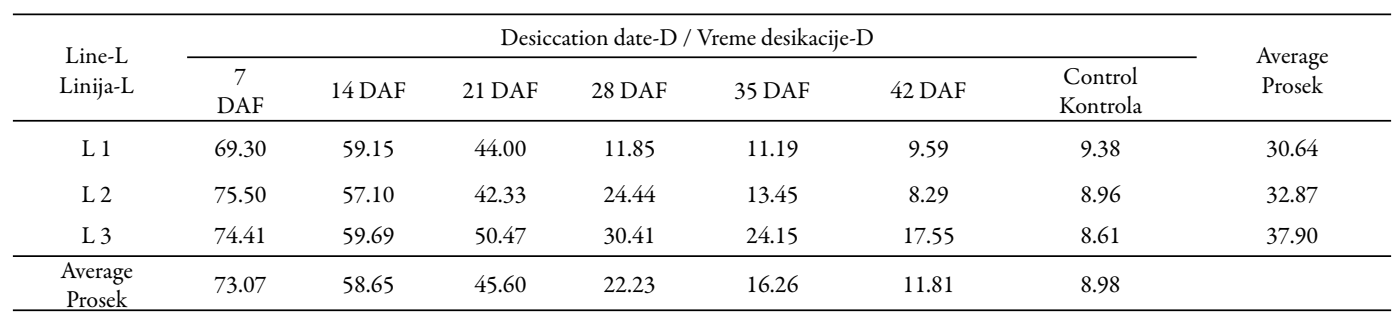

Table 2. Seed protein content (\%)

Tabela 2. Sadržaj proteina u semenu (\%)

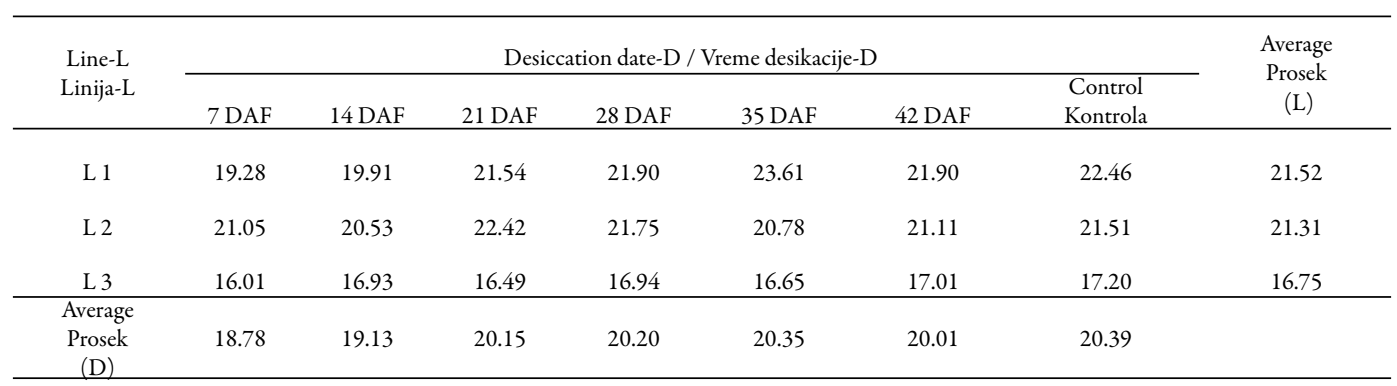

\begin{tabular}{cccc}
\hline LSD & L & D & D*L \\
\hline $5 \%$ & 0.67 & 0.57 & 0.98 \\
$1 \%$ & 1.11 & 0.76 & 1.31 \\
\hline
\end{tabular}


Miklič (2001) found the highest protein content 7 DAF, at the seed moisture of $65.58 \%$. Gubbels \& Dedio (1985) recorded that protein content reached constant level at seed moisture of $45 \%$ and 64\%. Radić (2006) determined stabilization of protein content in seed at the treatment 14 DAF. Partial degradation of protein during seed maturation was reported by Bolyakina \& Raikhman (1999). Steer et al. (1984), Goffner et al. (1988), Ploschuk \& Hall (1997) and Jovanović et al. (2003) reported that protein accumulation in sunflower occurs at a greater rate during the first part of the seed filling.

In case of the line $\mathrm{L} 1$, the highest protein content was obtained with the treatment 35 DAF (23.61\%), the lowest with the treatment 7 DAF (19.28\%). The treatment 35 DAF had highly significant protein content in relation to all other treatments except the control, where it was significant $(p=0.05)$. In case of the line
L2, the highest protein content was obtained with the treatment 21 DAF $(22.42 \%)$, and the lowest with the treatment $14 \mathrm{DAF}(20.53 \%)$. The protein content in the treatment $21 \mathrm{DAF}$ was highly significant in relation to the treatments 7 DAF, $14 \mathrm{DAF}$ and $35 \mathrm{DAF}$, and significant in relation to the treatment $42 \mathrm{DAF}$. No significant difference was found among the treatments 21 DAF, $28 \mathrm{DAF}$ and the control. In case of the line L3, the highest protein content was obtained with the control (17.20\%), and the lowest with the treatment 7 DAF (16.01\%). The control had significant protein content only in relation to the treatment 7 DAF. There was no significant difference in protein content between control and all other treatments.

Coefficients of determination, which showed the influence of seed moisture on protein content, were different between the lines. The highest impact was obtained in the $\mathrm{L} 1\left(0.842^{*}\right)$, medium
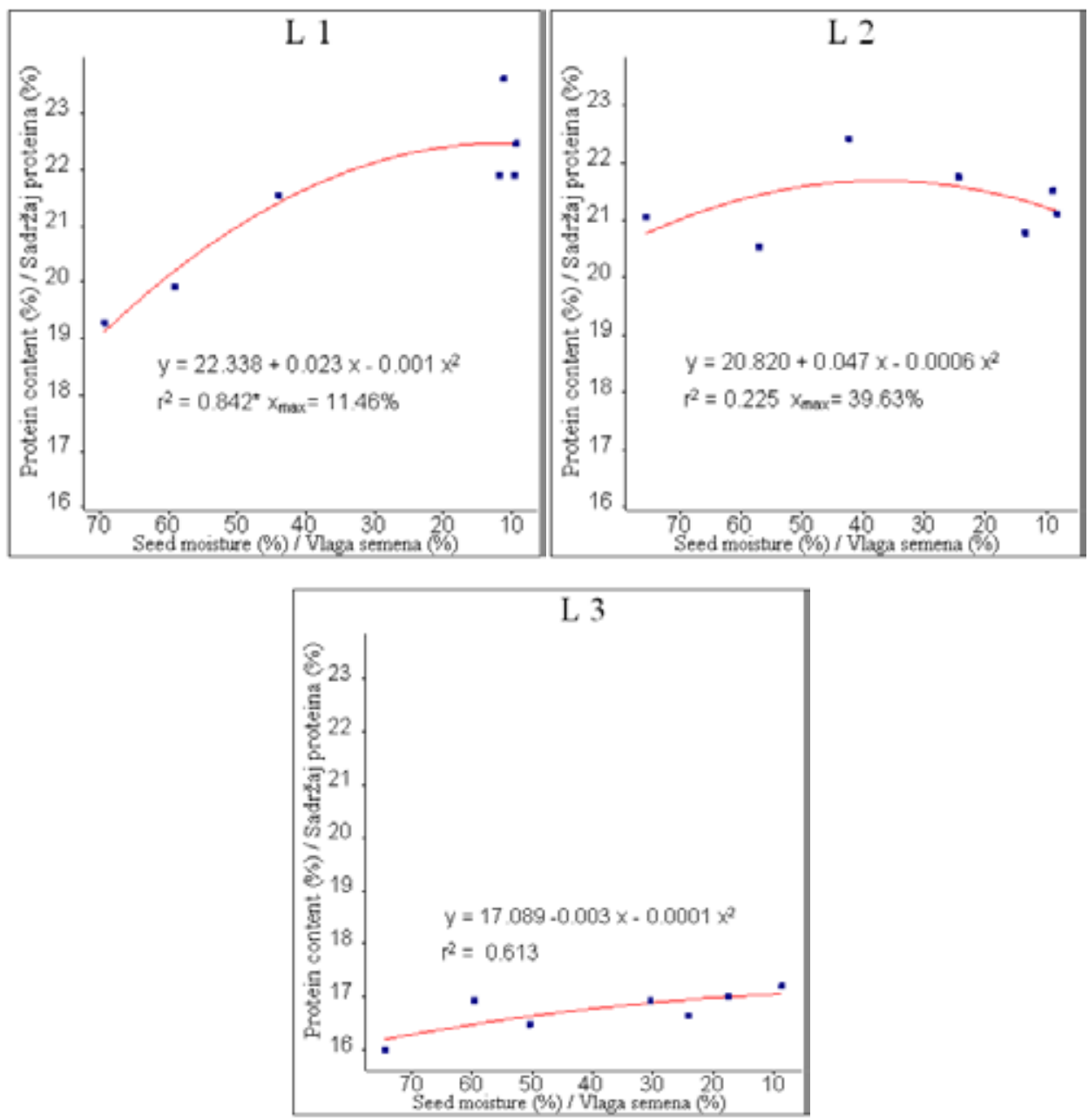

Fig. 1. Effect of seed moisture on seed protein content at the time of desiccation Grafikon 1. Uticaj vlažnosti semena u momentu desikacije na sadržaj proteina u semenu 
in the L3 (0.613), and the lowest in the line L2 (0.225). The impact in the line L1 was significant, while the impacts in the lines L2 and L3 were not significant. Miklič (2001) recorded significant and highly significant impact of seed moisture on protein content. In the lines L1 and L 2 curve of regression exhibited maximum protein content at moisture contents of $11.46 \%$ and $39.63 \%$. In the case of line L3, with decreasing of moisture content, protein content was constantly increasing (Fig. 1).

\section{Conclusion}

The following conclusions can be drawn based on the obtained results:

The highest seed protein content was determined in the line L1. It was highly significant in relation to the line $\mathrm{L} 3$ and at the same level as the line L2.

The control had the highest average seed protein content, but there was no significant increase in protein content in regard to DAF-21. This can indicate that protein accumulation in sunflower seed was completed about 21 DAF at the seed moisture of $45 \%$, i.e. desiccation after that would not cause decrease of seed protein content.

Results of this experiment have shown that optimal time of desiccation should individually be tested for each genotype.

\section{Literature}

Bolyakina YUP, Raikhman LA (1999): Structural aspects of protein accumulation in developing sunflower seeds. Russ. J. Plant Physiol. 46: 340-348

Đukić N, Malidža G, Bugarin R, Sedlar A, Turan J (2007): Mehanizovana desikacija u proizvodnji uljanih kultura. Savremena poljoprivredna tehnika 33: 250-262
Goffner D, Cazalis R, Percie Du Sert C, Calmes J, Cavalie G (1988): ${ }^{14} \mathrm{C}$ photoassimilate partitioning in developing sunflower seeds. J. Exp. Bot. 39: 1411-1420

Gubbels GH, Dedio W (1985): Desiccation of sunflower with diquat. Can. J. Plant Sci. 65: 841-847

Hill J, Knight BAG, Ogilvy JME (1974): The significance of a new harvest technology in the intensive production of sunflower. VI International Sunflower Conference, July 22-24, Bucharest, Romania, Book of Proceedings, 589-596

Jevtić S, Milošević R, Šuput M, Mustapić Z, Gotlin J, Uzunoski M, Klimov S, Đorđevski J, Spanring J, Miletić N (1986): Posebno ratarstvo. Naučna knjiga, Beograd

Jovanović D, Sakač Z, Lečić N (2003): Uticaj faktora spoljne sredine na sintezu proteina i ulja u semenu suncokreta u 2002. godini. Zbornik radova Instituta za ratarstvo i povrtarstvo 38 : 209-222

Miklič V, Balalić I, Jocić S, Marinković R, Cvejić S, Hladni N, Miladinović D (2010): Ocena stabilnosti prinosa semena i ulja NS hibrida suncokreta u mikro-ogledima i preporuka sortimenta za setvu u 2010. godini. Ratar. Povrt. 47: 131-146

Miklič V, Maširević S, Škorić D (2006): Hemijska desikacija u proizvodnji hibridnog semena suncokreta. Zbornik naučnih radova Instituta PKB Agroekonomik 12: 87-95

Miklič V (2001): Uticaj momenta desikacije na semenski kvalitet i prinos suncokreta. Doktorska disertacija. Poljoprivredni fakultet, Novi Sad

Kovčin S, Stanaćev V (2006): Biodizel povećava proizvodnju proteinskih hraniva za ishranu stoke. Traktori i pogonske mašine 11:53-59

Lević J D, Sredanović S A, Đuragić O M (2005): Proteini suncokretove sačme kao hrana za brojlere. APTEFF 36: 3-10

Ploschuk E, Hall A (1997): Maintenance respiration coefficient for sunflower achenes is less than that for the entire capitulum. Field Crops Res. 49: 147-157

Radić V (2006): Effect of maturation period on seed quality; optimum time for desiccation in sunflower (Helianthus annuus L.) genotypes. Helia 29: 145-152

Shewry RP, Napier AJ, Tatham SA (1995): Seed Storage Proteins: Structures and Biosynthesis. The Plant Cell 7: $945-956$

Stanković V, Dijanović D, Mihajlović I (2003): Rezultati oplemenjivanja suncokreta i lana u Centru za poljoprivredna i tehnološka istraživanja-Zaječar. Selekcija i semenarstvo 9: 95-99

Steer T, Hocking P, Kortt A, Roxburgh C (1984): Nitrogen nutrition of sunflower (Helianthus annuus $\mathrm{L}$.): yield components, the timing of their establishment and seed characteristics in response to nitrogen supply. Field Crops Res. 9: 219-236

\section{Sadržaj proteina u semenu suncokreta u zavisnosti od vremena desikacije i vlažnosti semena}

\section{Petar Čanak • Velimir Radić • Milan Jocković • Radovan Marinković • Mihajlo Ćirić • Jelena Mrđa • Vladimir Miklič}

Izvod: Cilj ovog ogleda je bilo ispitivanje uticaja vremena desikacije i vlažnosti semena na sadržaj proteina u semenu suncokreta. Kao materijal su korišćene tri nove komercijalne linije novosadskog Instituta za ratarstvo i povrtarstvo (L1, L2 i L3). Desikacija je izvođena preparatom Reglone forte $\left(21\right.$ ha $\left.^{-1}\right)$ svakih 7 dana od završetka cvetanja do žetvene zrelosti. Sadržaj proteina utvrđen je klasičnom metodom po Kjeldahl-u. Stabilizacija sadržaja proteina utvrđena je kod tretmana koji je izveden 21 dan posle cvetanja (DPC) pri vlažnosti semena od oko 45\%. Regresionom analizom utvrđen je najviši i statistički značajan uticaj vlažnosti semena u momentu desikacije na sadržaj proteina kod linije L1, dok kod druge dve linije nije bilo značajnog uticaja.

Ključne reči: desikacija, proteini u semenu, sadržaj proteina, seme suncokreta, vlažnost 